\title{
Improved potato microclonal reproduction with the plant growth-promoting rhizobacteria Azospirillum
}

\author{
Oksana V. Tkachenko ${ }^{1}$ - Nina V. Evseeva ${ }^{2}$ Natalya V. Boikova ${ }^{1}$ - Larisa Yu. Matora ${ }^{2}$. $^{2}$ \\ Gennady L. Burygin ${ }^{2} \cdot$ Yuriy V. Lobachev ${ }^{1} \cdot$ Sergei Yu. Shchyogolev ${ }^{2}$
}

Accepted: 24 March 2015 / Published online: 23 April 2015

(C) INRA and Springer-Verlag France 2015

\begin{abstract}
Microclonal propagation in vitro is being actively used in the production of healthy planting material of food and ornamental plants. However, it needs further improvement to increase the growth rates of microclones in vitro and enhance regenerant survivability ex vitro. A promising approach to this end could be inoculating in vitro-micropropagated plants with plant growth-promoting rhizobacteria, specifically Azospirillum. However, the influence of Azospirillum inoculation on microclone behavior throughout the production process, including plant adaptation ex vitro and food crop productivity, has been underinvestigated. In this study, in vitrogrowing potato (Solanum tuberosum L.) microclones were inoculated with Azospirillum brasilense strain Sp245. The microclones were then grown on in soil in the greenhouse and field, with the experiment lasting for 120 days. Rootassociated bacteria were identified immunochemically, and the mitotic index of root meristematic cells was determined by a cytological method. The plant morphological parameters determined were shoot length, number of nodes per shoot, number of roots per plant, maximal root length, leaf area, percentage of surviving plants in the soil, and tuber yield and weight. Our results show that bacterial inoculation of potato microclones in vitro enhances plant adaptive capacity ex vitro and increases minituber yield. The percent survival index of field-grown inoculated plants was 1.5 -fold greater
\end{abstract}

Nina V. Evseeva

evseeva@ibppm.sgu.ru

1 Vavilov Saratov State Agrarian University, 1 Teatralnaya Ploshchad, Saratov 410012, Russian Federation

2 Institute of Biochemistry and Physiology of Plants and Microorganisms, Russian Academy of Sciences, 13 Prospekt Entuziastov, Saratov 410049, Russian Federation than that of uninoculated plants. The overall tuber weight per plant was more than $30 \%$ greater in the inoculated plants than it was in the control ones. For all cultivars on average, tuber yield per square meter increased by more than $45 \%$ as a result of inoculation in vitro. This study is the first to report that Azospirillum inoculation of potato microclones not only improves the quality of planting material produced in vitro but also significantly increases minituber yield through enhancing plant adaptive capacity in the field.

Keywords Solanum tuberosum L · Azospirillum brasilense . Microclonal propagation $\cdot$ In vitro $\cdot$ Ex vitro

\section{Introduction}

Culturing of apical meristems followed by plant microclonal propagation in vitro has been used widely in current biotechnology to produce genetically homogeneous and virus-free planting material of food and ornamental crops (George and Debergh 2008). However, this method needs to be optimized to achieve higher growth rates of microclones and better survival of regenerated plants under soil conditions (ex vitro). The adaptation of test-tube plants to growth in soil is extremely expensive and labor-consuming. Plants that propagate in vitro are sterile, have weak protective systems, and often are difficult to adapt ex vitro, with high percentages of regenerant deaths (Demenko and Lebedev 2011). After being transferred to soil, such plants often become stunted, shed their leaves, and die, primarily because the improper functioning of their stomatal apparatus causes them to lose large amounts of water. Under in vitro conditions, root hairs either do not form or form in numbers insufficient for a normal supply of water and mineral components from soil solution. Therefore, for some species (mostly woody plants or 
legumes), a number of symbiological techniques have been utilized, including artificial mycorrhization (Estrada-Luna et al. 2000) and combined treatment with vesicular arbuscular mycorrhizal fungi and Rhizobium (Balla et al. 1997). LópezLima et al. (2013) used the nematophagous fungus Paecilomyces sp. to efficiently reduce the population of the potato cyst nematode Globodera rostochiensis. Work is also ongoing with associative plant growth-promoting rhizobacteria, typically methylobacteria and pseudomonads (Bensalim et al. 1998; Zaharchenko et al. 2012), which can improve the growth characteristics of microclones in vitro and stimulate the acclimatization of regenerants ex vitro.

Plant growth-promoting rhizobacteria supply plants with additional mineral and organic nutrients, phytohormones, and available nitrogen (Vacheron et al. 2013; Bashan et al. 2014; Pii et al. 2015). They also participate in the competitive bioregulation of soil microbial associations (Beneduzi et al. 2012) and induce systemic resistance in the macroorganisms to abiotic and biotic environmental factors (Zamiodis and Pieterse 2012; Paul and Lade 2014). Prominent among them are associative bacteria of the genus Azospirillum, which, in particular, can enhance the growth and development of potato microclones in vitro (Volkogon et al. 2006), improve the acclimation of fruit plants ex vitro (Vettori et al. 2010), and increase the productivity of agricultural plants in vivo (Bashan and de-Bashan 2010; Fibach-Paldi et al. 2012). There is, however, a deficit of data to show the influence of bacterial inoculation not only on the growth characteristics of plants cultured in vitro (Volkogon et al. 2006) but also on their adaptation to growth ex vitro.

We hypothesized that developing an active association between in vitro-growing potato (Solanum tuberosum L.) microclones and the bacterium Azospirillum brasilense Sp245 may not only improve the quality of planting material but also significantly increase minituber yield ex vitro. These improvements would come from the micropartner's positive influence on the resulting plant regenerants throughout acclimatization and from the enhancement of plant adaptive capacity under stressful field conditions. The major aim of the research reported here was to experimentally verify this hypothesis.

\section{Materials and methods}

\subsection{Culturing of potato microclones in vitro}

Four potato cultivars were used: Rosara (very early; SaKa Pflanzenzucht GmbH \& Co. KG, Germany), Kondor (earlyripening; Agrico, The Netherlands), Nevsky (medium-early; ZAO Vsevolozhskaya selektsionnaya stantsiya, Russian Federation), and Aurora (medium-ripening; ZAO Vsevolozhskaya selektsionnaya stantsiya, Russian
Federation). The cultivars were from the plant collection maintained by the Department (kafedra) of Crop Breeding, Selection, and Genetics of the Agronomy Faculty at Vavilov State Agrarian University in Saratov, Russian Federation. In vitro-micropropagated plants were separated into microcuttings with one leaf and one lateral bud and were placed in test tubes containing a hormone-free, low-agar (3.5 $\mathrm{g} \mathrm{L}^{-1}$ ) Murashige-Skoog nutrient medium (Murashige and Skoog 1962). The plants were then transferred to a rack and grown for 20 days under the same conditions (temperature, $24{ }^{\circ} \mathrm{C}$; air humidity, $60 \%$; light intensity, $60 \mu \mathrm{M} \mathrm{m}^{-2} \mathrm{~s}^{-1}$; day length, $16 \mathrm{~h}$ ). Morphological characteristics such as shoot length, number of nodes per shoot, number of roots per plant, and maximal root length were recorded every 5 days.

\subsection{Determination of the mitotic index of meristematic cells}

On day 20 of plant growth, root-associated bacteria were detected (see Sections 2.5 and 2.6) and the mitotic index of the meristematic cells of adventitious roots from Kondor microclones was determined conventionally (Iordansky 1965). Root tips (2-3 mm) were fixed in acetic acid-ethanol (1:3), stained with acetohematoxylin (Dia-M Co., Moscow, Russian Federation), macerated in cytase (a mixture of enzymes isolated from the stomach of the snail Helix pomatia; courtesy of M.I. Tsvetova, Science Research Institute of Agriculture in the South-East, Saratov), and viewed in a Leica DM 2500 microscope (Germany) at $\times 600$ magnification. Each experiment had three replicates, each analyzing root tips excised from five seedlings. In each root tip, not less than 1000 cells were analyzed.

\subsection{Inoculation of potato microcuttings}

A. brasilense Sp245 (Baldani et al. 1983), a micropartner forming associative relationships with the roots of many plant species, including potato, was obtained from the Collection of Rhizosphere Microorganisms at the Russian Academy of Sciences' Institute of Biochemistry and Physiology of Plants and Microorganisms in Saratov. The culture was grown at $28^{\circ} \mathrm{C}$ on a rotary shaker with vigorous agitation $(120 \mathrm{rpm})$ to the end of the exponential phase $(18 \mathrm{~h})$ in a liquid malatesalt medium of the following composition $\left(\mathrm{g} \mathrm{L}^{-1}\right)$ : Na malate, $5 ; \mathrm{KH}_{2} \mathrm{PO}_{4}, 0.4 ; \mathrm{K}_{2} \mathrm{HPO}_{4}, 0.4 ; \mathrm{NaCl}, 0.1 ; \mathrm{MgSO}_{4}, 0.2 ; \mathrm{FeSO}_{4}$ - $7 \mathrm{H}_{2} \mathrm{O}, 0.02 ; \mathrm{Na}_{2} \mathrm{MoO}_{4} \cdot 2 \mathrm{H}_{2} \mathrm{O}, 0.002 ;$ and $\mathrm{NH}_{4} \mathrm{Cl}, 1(\mathrm{pH}$ 6.8-7.0; Döbereiner and Day 1976). The cells were sedimented by centrifugation at $3000 \times g$ and were suspended in $0.12 \mathrm{M}$ phosphate-buffered saline ( $\mathrm{pH} 7.2$ ) composed as follows $\left(\mathrm{g} \mathrm{L}^{-1}\right): \mathrm{KH}_{2} \mathrm{PO}_{4}, 0.43 ; \mathrm{Na}_{2} \mathrm{HPO}_{4}, 1.68$; and $\mathrm{NaCl}$, 7.2. To wash the bacteria free of the culture liquid, we repeated the centrifugation in phosphate-buffered saline twice. Inoculation was performed by our modification of the 
procedure of Volkogon et al. (2006). For inoculation, $0.1 \mathrm{~mL}$ portions of the resulting bacterial suspension $\left(10^{8}\right.$ cells $\left.\mathrm{mL}^{-1}\right)$ were added to test tubes containing $10 \mathrm{~mL}$ of the MurashigeSkoog medium until the final bacterial concentration in the medium was $10^{6}$ cells $\mathrm{mL}^{-1}$. The controls were uninoculated plants grown on a bacteria-free Murashige-Skoog medium.

\subsection{Growth of potato plants ex vitro}

For adaptation ex vitro, the control and inoculated microplants, after being grown in vitro for 20 days, were transferred to pots of nonsterile soil. The pots were put on a rack in a greenhouse (temperature, $24{ }^{\circ} \mathrm{C}$; air humidity, $60 \%$; light intensity, $60 \mu \mathrm{M} \mathrm{m}^{-2} \mathrm{~s}^{-1}$; day length, $16 \mathrm{~h}$ ) for 10 days, after which plant morphological characteristics such as height, leaf number, and leaf area were recorded. The plants were then transplanted to a field plot in a checkrow pattern $0.4 \times 0.4 \mathrm{~m}$. The plot is located near the town of Marx in Saratov region, Russia (dark chestnut soil), at a latitude of $51^{\circ} 36^{\prime} 20.5^{\prime \prime} \mathrm{N}$ (51.605694) and a longitude of $46^{\circ} 31^{\prime} 29.72^{\prime \prime} \mathrm{E}$ (46.524922). The weather conditions for field adaptation and growth were not regulated and were stressful for the plants (the daytime air temperature sometimes exceeded $30{ }^{\circ} \mathrm{C}$, the relative humidity was less than $60 \%$, and the wind speed in a 1-m-high surface layer was greater than 3-5 $\mathrm{m} \mathrm{s}^{-1}$ ). During plant growth, the plot was watered, weeded, supplied with mineral fertilizers, and treated against diseases and pests. Three weeks after planting, as well as at the start of budding and flowering, the percentage of surviving plants, plant height, shoot and leaf numbers per plant, and leaf area were recorded. Tubers were harvested when vines senesced, and the number of tubers per plant, the weight of each tuber, and the overall tuber weight per plant were counted. The plants were grown in the field for 90 days.

\subsection{Microbiological test}

The viability of $A$. brasilense $\mathrm{Sp} 245$ associated with the roots of 20-day-old potato plants was determined by a method modified from that of Zvyagintsev (1991), with account taken of bacterial colonization of root segments. Segments about $5 \mathrm{~mm}$ in length were cut from different zones of adventitious roots from the experimental and control plants and were placed on the malate-salt medium (Döbereiner and Day 1976) containing $1.5 \%$ agar. The samples were cultured in a thermostat at $30{ }^{\circ} \mathrm{C}$ for 3 days. After that, the bacteria that had grown around the root segments were seeded on the malate-salt medium for immunodiffusion analysis.

\subsection{Immunodiffusion}

Double immunodiffusion in agarose gel was performed by the standard technique of Ouchterlony and Nilsson (1978). Strain- specific antibodies against $A$. brasilense $\mathrm{Sp} 245$ were raised as described by Matora et al. (1998). For bacterial preparations, the cells were washed in phosphate-buffered saline, sedimented by centrifugation, and treated with an extraction buffer ( $\mathrm{pH}$ 8.5) of $0.1 \mathrm{M}$ Tris- $\mathrm{HCl}, 10 \mathrm{mM}$ sodium ethylenediaminetetraacetate (EDTA), $0.1 \mathrm{mM}$ phenylmethylsulfonyl fluoride, and $1 \%$ Triton X-100 at room temperature for $30 \mathrm{~min}$. The amount of EDTA was $0.05 \mathrm{mM} \mathrm{g}^{-1}$ of wet cells. The extract was freed from the cells by centrifugation, and precipitation was run on $6 \times 9 \mathrm{~cm}$ glass plates in $1 \%$ agarose gel prepared with phosphate-buffered saline. The experimental results were evaluated after 18-20 h. The plates were dried, stained with Coomassie Brilliant Blue R-250, and destained in an aqueous solution of $45 \%$ ethanol and $10 \%$ acetic acid.

\subsection{Statistics}

The experiment was conducted twice (in 2012 and 2013). The experimental and control treatments each had 30 test tubes with plants of each cultivar used. Data from all experiments were processed by two-way ANOVA, which allows evaluation not only of the differences between all treatments but also of the significance of differences for each factor studied (in this case, factor A, reflecting bacterial influence on plant growth and development, and factor B, reflecting the influence of the peculiarities of the genotypes used). The analysis was run with the AGROS program package for statistical and biometrical-genetic analysis in plant breeding and selection (Version 2.09; Department of Statistical Analysis, Russian Academy of Agricultural Sciences). Least significant differences $\left(\mathrm{LSD}_{0.05}\right)$ were determined at a significance level of $p=$ 0.05 . Values followed by different letters differed significantly at $p \leq 0.05$ according to Duncan's multiple range test. In the tables, the letters a, b, c., etc. refer to the sets of data that differed significantly when ANOVA yielded a significant result.

\section{Results and discussion}

\subsection{Bacterial influence on the growth and development of potato microclones in vitro}

Our results show that on day 5 of growth, all inoculated microcuttings began to develop one to three rootlets and lateral buds started to grow. None of the test tubes showed opacity around the microcuttings, bacterial films on the surface of the medium, or other signs of contamination.

As found by two-way ANOVA, the inoculated plants of all four cultivars developed more nodes and roots on day 20 of growth than did the control plants (Fig. 1a; Table 1). In addition, the inoculated plants of the early-ripening cultivars Kondor, Rosara, and Nevsky had greater average root lengths 
Fig. 1 Azospirillum inoculation in vitro during microclonal propagation of potato improves the quality of planting material and increases yield under field conditions (ex vitro). a Effect of inoculation with $A$. brasilense Sp245 on the development of in vitro-growing Nevsky microclones. b Growth of plants in pot soil ex vitro. The minitubers grown ex vitro from the Nevsky microclones inoculated in vitro with A. brasilense $\mathrm{Sp} 245$ : c experiment; $\mathbf{d}$ control
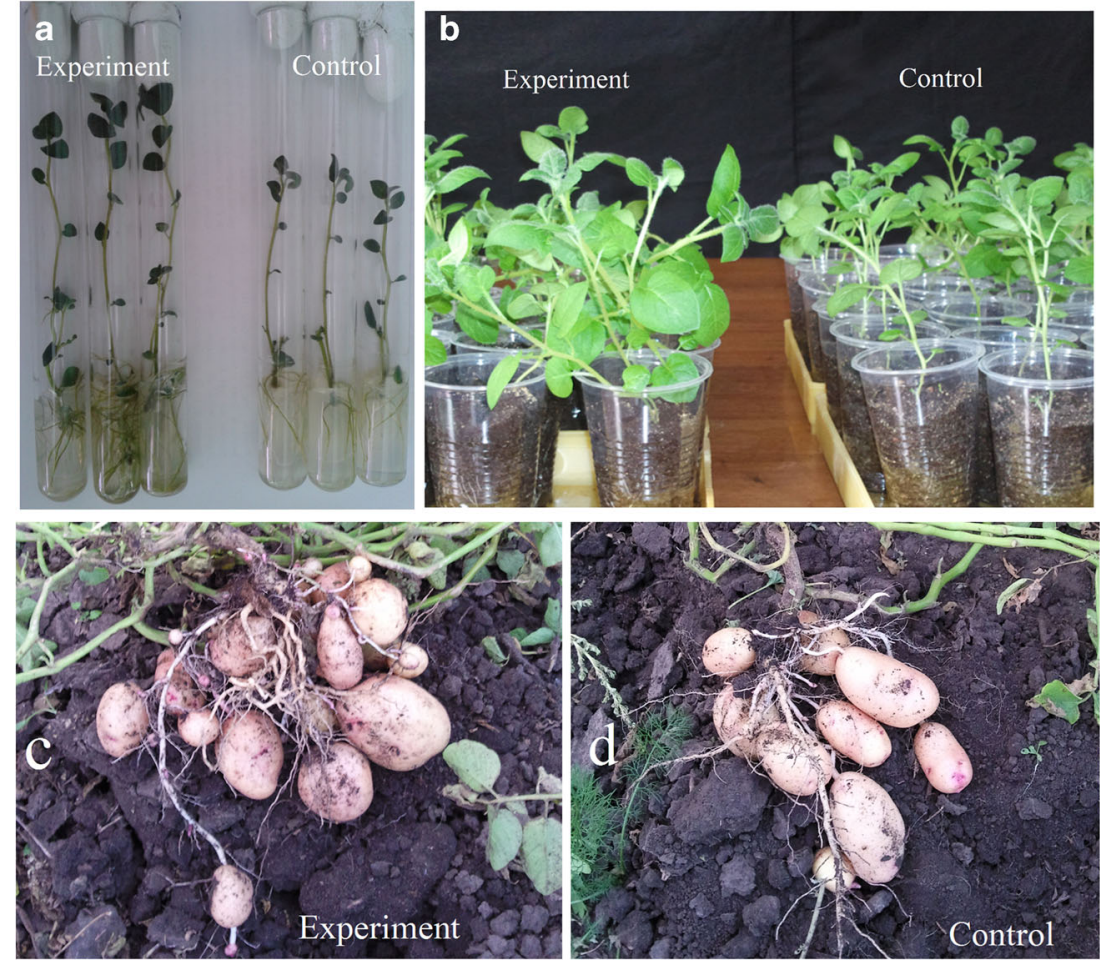

than did the sterile plants. An exception was the mediumripening cultivar Aurora, in which the average root length did not differ significantly from that of the controls.

Although there were no significant differences in shoot length between inoculated and control plants, an analysis for factor A (bacterial influence) showed that in all cultivars on average, inoculation had a significant positive effect on all characteristics considered, including shoot length.

Azospirillum inoculation enhanced the mitotic activity of the root meristematic cells of the potato microclones. On day 20 of growth, the mitotic index of the meristematic cells of the inoculated Kondor plants was about 2-fold higher than that for the controls: 2.3 vs. $1.3 \%\left(\operatorname{LSD}_{0.05}=0.2 \%\right)$. This finding is consistent with our previous data from a study of wheat seedling inoculation in vivo (Evseeva et al. 2011) and with the data of Levanony and Bashan (1989). It is possible that the mitotic activity enhancement activated the morphogenetic program of development of regenerated plants, which is what we observed in recording the morphological characteristics of the inoculated plants on day 20 of growth (Table 1).

The microbiological test showed that in the experimental treatments, the root segments were covered with bacteria on day 3 of growth in petri dishes containing MSM (Fig. 2a). The bacteria were identified as A. brasilense Sp245 by an immunochemical assay with strain-specific antibodies (Fig. 2b).

Our present data agree with those of Volkogon et al. (2006), who found that Azospirillum inoculation of in vitro-growing potato microclones increased the intensity of shoot (1.5-2- fold) and root (2-2.5-fold) development. From our data, the growth rates of the inoculated plants also increased as compared to the control values, and the inoculated plants had a better developed root system with many points of growth (Table 1). However, this work differs from Volkogon et al.'s (2006) in that the influence of azospirilla on the growth of various potato genotypes in vitro has been examined in a broader view and the adaptation of these plants ex vitro has been assessed for the first time.

\subsection{Bacterial influence on the adaptation of potato microclones ex vitro}

As a result of bacterial inoculation in vitro, the next stage (growth in soil) replaced sterile plants with an actively functioning, stable associative plant-microbe system. When the plants were transferred to soil in the greenhouse, favorable conditions were generated that reduced the stress of acclimatization. Because of this, all plants regained turgor within a day after being moved to soil. On day 3 , signs emerged that new leaves were being formed. The plant survival index was $100 \%$, so we were unable to judge the effect of bacteria at this stage. However, after 10 days of acclimatization, some differences were noted between inoculated and sterile plants. Specifically, the inoculated plants exhibited statistically significant increases in node and leaf numbers (Aurora and Rosara), a slight increase in shoot length (Condor), and an increase in leaf area (Nevsky), as compared to the controls (Fig. 1b, Table 2). In all cultivars on average, the 


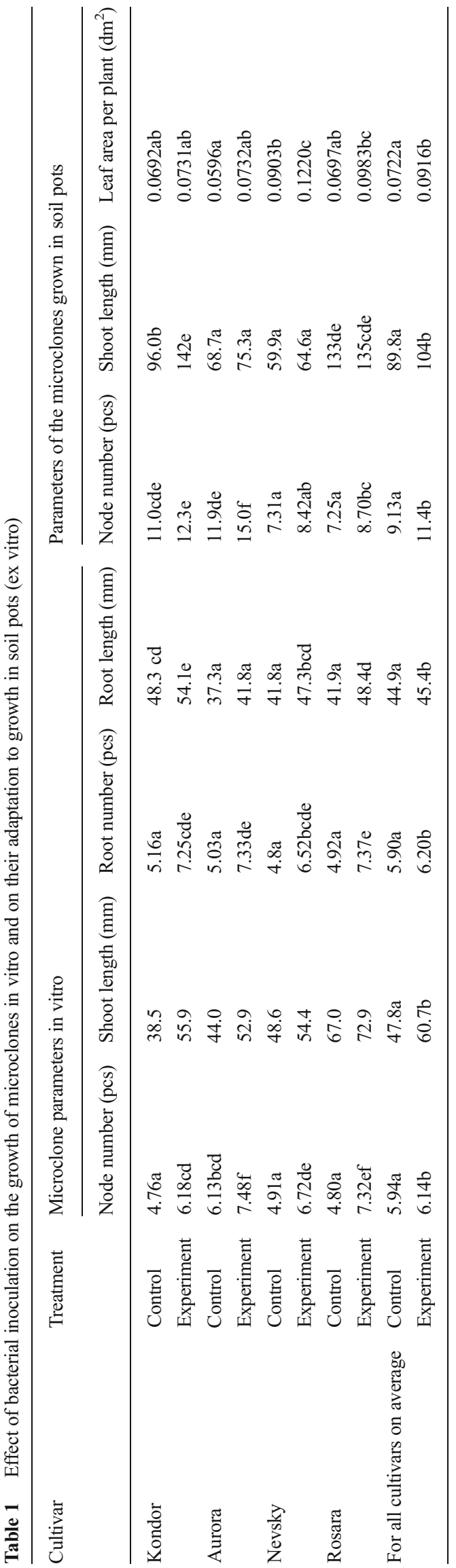

establishment of a plant-rhizobacterial association (factor A) significantly improved the rate of shoot growth through an increased shoot length, the formation of new nodes with leaves, and an increased leaf surface area.

After 10 days of growth in the greenhouse, the in vitromicropropagated plants not only regained stem and leaf turgor but also formed two to three new leaves. This indicated that the ex vitro acclimatization period had ended and that the potato plants inoculated at the stage of microclonal propagation in vitro were quite successful in tolerating the transfer to soil under controlled greenhouse conditions.

Zaharchenko et al. (2012) reported that methylobacteria had a significant positive effect on growth of the above- and belowground portions of tobacco, rape, and cabbage when micropropagated plants were moved to pots of soil after 8 weeks of growth in vitro. In our experiment, the adaptation took just 10 days, possibly accounting for the lack of a substantial influence of bacteria on plant growth.

\subsection{Bacterial influence on the field growth of in vitro-micropropagated plants and on the yield of tubers}

The plants were then transplanted to a field plot. Under the uncontrolled stress conditions, 75 to $88 \%$ of the plants died. However, the inoculated plants tolerated the stress much better than did their sterile counterparts. For all cultivars individually and on average, the percent survival index of the inoculated plants was 1.5-fold greater than that of the sterile plants (Fig. 3a).

Plants that had adapted to growing in the field started to form new leaves and stems. At the start of budding and flowering, after the vegetative mass had formed, plant leaf area was measured and found to be significantly greater in the inoculated plants than in the control ones. This fact was established for all cultivars individually and on average.

When vines senesced, the number of tubers and the overall tuber weight per plant were counted. The data showed that for all cultivars except Aurora, the numbers of tubers formed by the experimental and control plants were not significantly different and were dependent to a greater extent on the peculiarities of the cultivar used. However, an analysis for factor A (bacterial influence) showed that in all cultivars on average, inoculation increased the number of tubers per plant (Table 2). In all cultivars individually (except the very early cultivar Rosara) and on average, the overall tuber weight per plant was more than $30 \%$ greater in the inoculated plants than it was in the control ones. On a per square meter basis, all cultivars taken together and each one individually exhibited significantly higher tuber yields (by more than $45 \%$ on average) as a result of having been inoculated in vitro (Figs. 1c, d and 3b). 


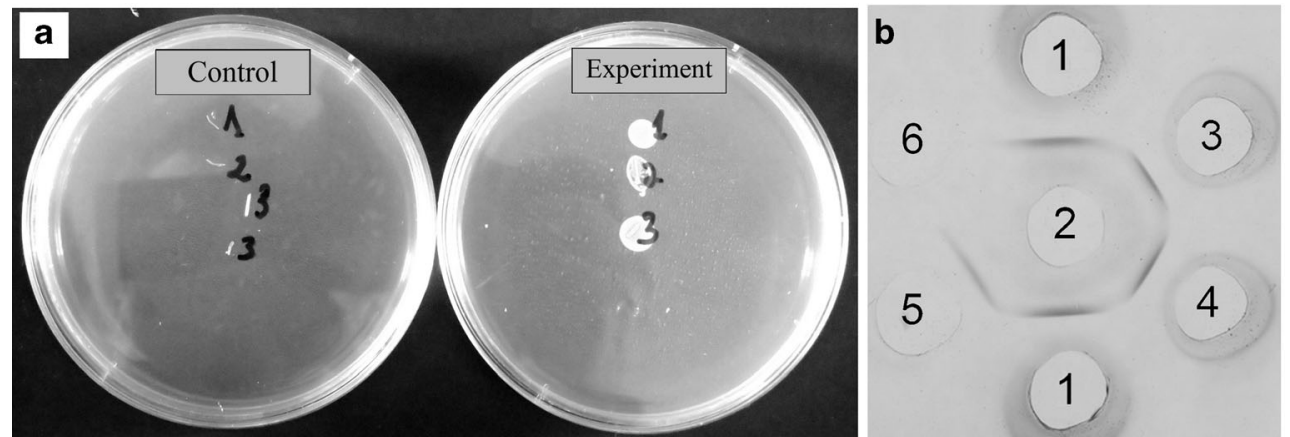

Fig. 2 Detection of A. brasilense Sp245 in the microbiological test (a) and in the immunochemical assay system (b) for the Kondor potato cultivar. A: 1, 2, 3, root segments from 20-day-old potato microclones grown in vitro; B: 1, 2, 3, extracts from the bacteria that had grown around

Several authors have also reported increased potato yields from tubers treated with plant growth-promoting rhizobacteria, in particular pseudomonads, before planting (Grosch et al. 2005; Rosyidah et al. 2013; Vacheron et al. 2013). Besides promoting plant growth, some strains of Bacillus, Methylobacter, Pseudomonas, Azospirillum, and combined treatment with vesicular arbuscular mycorrhizal fungi and Rhizobium influence stress resistance in plants and crop yields (Bensalim et al. 1998; Dey et al. 2004; Saleh and Saleh 2006; Maksimov et al. 2011; Zaharchenko et al. 2012; Pii et al. 2015). A. brasilense Sp245 increases the resistance of wheat to osmotic stress by improving the plant's ability to absorb water and nutrients (Creus et al. 2004) and promotes the formation of root hairs in tomato (Creus et al. 2005).

At this point in our research, we cannot suggest any concrete mechanisms that might be responsible for the effect of Azospirillum on the growth and development of potato microclones. Azospirilla are known to be effective $\mathrm{N}_{2}$ fixers, P mobilizers, phytohormone producers, and biocontrol agents (Bashan and de-Bashan 2010; Venieraki et al. 2011; FibachPaldi et al. 2012). The use of azospirilla for inoculation at the early stages of microclonal propagation, as against other plant growth-promoting rhizobacteria, was dictated by the greater the corresponding root segments; 4, extract from A. brasilense Sp245 cells (positive control); 5, antibodies; 6, phosphate-buffered saline (negative control)

concentration of bacteria in the rhizosphere. In our experiments, this fact was vividly confirmed by the absence of bacterial overgrowth on the culture medium in vitro (Fig. 1a). We speculate also that in addition to promoting plant growth, azospirilla, like methylobacteria and pseudomonads, can induce systemic resistance to stress in regenerated potato plants. An indication of this can be found in a study by Tortora et al. (2012). In our experiments, the inoculated plants began vegetative growth quicker (at the cost of their enhanced adaptability) and formed more leaves with a larger surface area (Table 2). The better developed assimilating leaf surface enabled the plants to synthesize greater quantities of organic substances. Although the bacteria had little effect on tuber initiation, the overall tuber weight in the inoculated plants was much greater than that in the control ones (Table 2). Consequently, the increased adaptability of the plants in association with Azospirillum improved not only plant survival but also tuber yield (Fig. 3).

The results of our study also demonstrate that bacterial inoculation of plants in vitro has a positive effect on the development of the root system. This seems to occur through the synthesis of phytohormones and through the enhancement of the functional activity of root meristematic cells (Bashan and
Table 2 Effect of bacterial inoculation in vitro on the growth of microclones in the field (ex vitro)

\begin{tabular}{llcll}
\hline Cultivar & Treatment & $\begin{array}{l}\text { Leaf area per } \\
\text { plant }\left(\mathrm{dm}^{2}\right)\end{array}$ & $\begin{array}{l}\text { Number of tubers per } \\
\text { plant }(\mathrm{pcs})\end{array}$ & $\begin{array}{l}\text { Overall tuber weight per } \\
\text { plant }(\mathrm{kg})\end{array}$ \\
\hline Kondor & Control & $5.99 \mathrm{a}$ & $7.75 \mathrm{a}$ & $0.315 \mathrm{ab}$ \\
& Experiment & $15.2 \mathrm{~b}$ & $10.5 \mathrm{ab}$ & $0.522 \mathrm{~cd}$ \\
Aurora & Control & $6.78 \mathrm{a}$ & $11.1 \mathrm{ab}$ & $0.281 \mathrm{a}$ \\
& Experiment & $14.5 \mathrm{~b}$ & $17.8 \mathrm{~d}$ & $0.567 \mathrm{~cd}$ \\
Nevsky & Control & $7.96 \mathrm{a}$ & $6.25 \mathrm{a}$ & $0.288 \mathrm{a}$ \\
& Experiment & $26.0 \mathrm{~b}$ & $9.75 \mathrm{ab}$ & $0.415 \mathrm{~b}$ \\
Rosara & Control & $6.88 \mathrm{a}$ & $14.6 \mathrm{c}$ & $0.727 \mathrm{~d}$ \\
& Experiment & $10.3 \mathrm{~b}$ & $16.4 \mathrm{~cd}$ & $0.764 \mathrm{~d}$ \\
For all cultivars on & Control & $6.90 \mathrm{a}$ & $10.4 \mathrm{a}$ & $0.353 \mathrm{a}$ \\
average & Experiment & $16.5 \mathrm{~b}$ & $13.1 \mathrm{~b}$ & $0.564 \mathrm{~b}$ \\
\hline
\end{tabular}




\section{Azospirillum inoculation effects}

a

Survival index (\%)

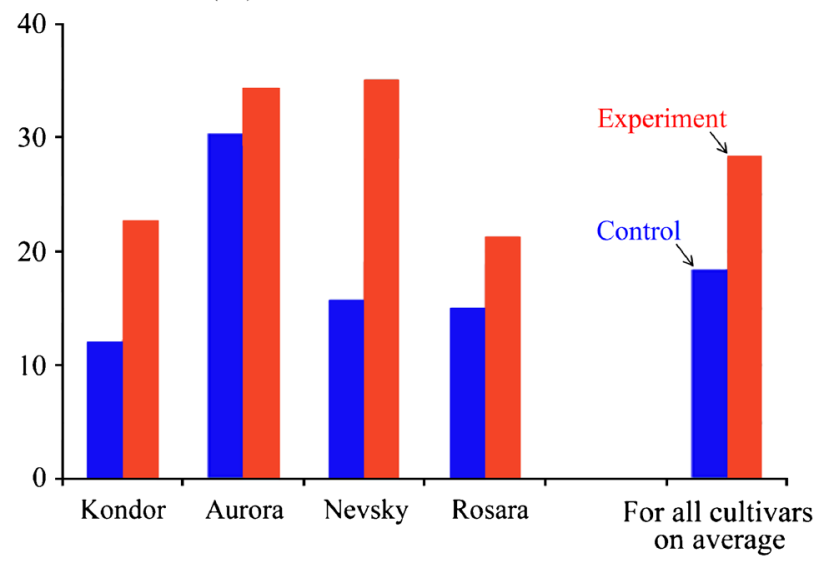

b

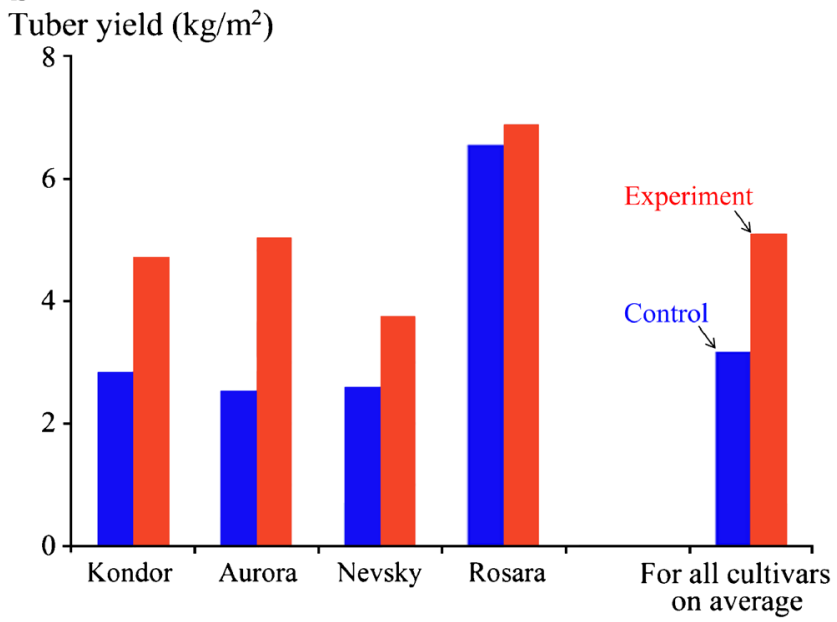

Fig. 3 Azospirillum inoculation in vitro significantly increases potato survival in the field (a) and tuber yield (b). According to the statistical treatment described in Section 2.7, the differences between control and experimental results were significant $(p \leq 0.05)$ for all cultivars individually (except for Rosara in Fig. 3b) and on average

de-Bashan 2010; Evseeva et al. 2011). Ultimately, this leads to better rooting of microclones in pot soil, better survival in the field, accelerated biomass accumulation, and increased tuber yield.

In summary, this study is the first to have reported systematic observations of effects of Azospirillum inoculation during the microclonal propagation of potato in vitro throughout the production process, from growth of microclones to survival of planting material in soil ex vitro to harvesting. It has been established that Azospirillum inoculation of potato microclones not only improves the quality of the in vitro-produced planting material but also significantly increases minituber yield ex vitro through enhancing plant adaptive capacity under stressful field conditions.

\section{Conclusion}

Microclonal propagation in vitro, used actively in the production of healthy planting material of food and ornamental plants, needs further improvement to increase the growth rates of microclones and enhance regenerant survivability ex vitro. A promising approach to this end is to inoculate in vitromicropropagated plants with plant growth-promoting rhizobacteria. Several authors have described a positive effect of methylobacteria and pseudomonads on the development of in vitro-micropropagated plants when cultured in vitro and ex vitro.

Of particular interest from this standpoint are associative nitrogen-fixing bacteria of the genus Azospirillum, which occur widely in diverse climatic zones and exert positive effects when in ectosymbiotic relationships with many plant species and cultivars. However, we are not aware of any published studies reporting systematic observations of effects of Azospirillum inoculation during the microclonal propagation of potato in vitro throughout the production process, from growth of microclones to survival of planting material in soil ex vitro to harvesting. Here, we have demonstrated for the first time that Azospirillum inoculation of potato microclones in vitro not only improves the quality of the produced planting material but also significantly increases minituber yield ex vitro through enhancing plant adaptive capacity under stressful field conditions. This might serve as a way to improve the agrobiotechnology of producing potato seed material of significantly better quality.

Acknowledgments Thanks are due to Mr. Dmitry N. Tychinin (IBPPM RAS) for translating the original manuscript into English.

\section{References}

Baldani VLD, Baldani JI, Döbereiner J (1983) Effects of Azospirillum inoculation on root infection and nitrogen incorporation in wheat. Can J Microbiol 29:924-929. doi:10.1139/m83-148

Balla I, Vértesi J, Köves-Péchy K, Vörös I, Bujtás Z, Biró B (1997) Acclimation results of micropropagated black locust (Robinia pseudoacacia L.) improved by symbiotic microorganisms. In: Cassels AC (ed) Pathogen and microbial contamination management in micropropagation. Kluwer Academic Publishers, pp. 351355. doi: 10.1007/978-94-015-8951-2_43

Bashan Y, de-Bashan LE (2010) How the plant growth-promoting bacterium Azospirillum promotes plant growth-a critical assessment. Adv Agron 108:77-136. doi:10.1016/S0065-2113(10)08002-8

Bashan Y, de-Bashan LE, Prabhu SR, Hernandez J-P (2014) Advances in plant growth-promoting bacterial inoculant technology: formulations and practical perspectives (1998-2013). Plant Soil 378:1-33. doi:10.1007/s11104-013-1956-x

Beneduzi A, Ambrosini A, Passaglia MD (2012) Plant growth-promoting rhizobacteria (PGPR): their potential as antagonists and biocontrol agents. Genet Mol Biol 35:1044-1051. doi:10.1590/S141547572012000600020 
Bensalim S, Nowak J, Asiedu SK (1998) A plant growth promoting rhizobacterium and temperature effects on performance of 18 clones of potato. Am J Potato Res 75:145-152. doi:10.1007/BF02895849

Creus CM, Sueldo RJ, Barassi C (2004) Water relations and yield in Azospirillum-inoculated wheat exposed to drought in the field. Can J Bot 82:273-281. doi:10.1139/B03-119

Creus CM, Graziano M, Casanovas EM, Pereyra MA, Simontacchi M, Puntarulo S, Barassi CA, Lamattina L (2005) Nitric oxide is involved in the Azospirillum brasilense-induced lateral root formation in tomato. Planta 221:297-303. doi:10.1007/s00425-005-1523-7

Demenko VI, Lebedev VG (2011) Adaptatsiya rastenii, poluchennykh in vitro, $\mathrm{k}$ nesteril'nym usloviyam (Adaptation of plants obtained in vitro to nonsterile conditions). Izv TSKhA, Moscow (in Russian) 1:60-70.

Dey R, Pal KK, Bhatt DM, Chauhan SM (2004) Growth promotion and yield enhancement of peanut (Arachis hypogaea L.) by application of plant growth-promoting rhizobacteria. Microbiol Res 159:371394. doi:10.1016/j.micres.2004.08.004

Döbereiner J, Day JM (1976) Associative symbioses in tropical grasses: characterization of microorganisms and dinitrogen-fixing sites. In: Newton WE, Nyman CJ (eds) Proceedings of the 1st international symposium on nitrogen fixation. Washington State University Press, WA, pp 518-538

Estrada-Luna AA, Davies FT Jr, Egilla JN (2000) Mycorrhizal fungi enhancement of growth and gas exchange of micropropagated guava plantlets (Psidium guajava L.) during ex vitro acclimatization and plant establishment. Mycorrhiza 10:1-8. doi:10.1007/ s005720050280

Evseeva NV, Matora LY, Burygin GL, Dmitrienko VV, Shchyogolev SY (2011) Effect of Azospirillum brasilense Sp245 lipopolysaccharide on the functional activity of wheat root meristematic cells. Plant Soil 346:181-188. doi:10.1007/s11104-011-0808-9

Fibach-Paldi S, Burdman S, Okon Y (2012) Key physiological properties contributing to rhizosphere adaptation and plant growth promotion abilities of Azospirillum brasilense. FEMS Microbiol Lett 326:99108. doi:10.1111/j.1574-6968.2011.02407.x

George EF, Debergh PC (2008) Micropropagation: uses and methods. In: George EF, Hall MA, De Klerk G-J (eds) Plant propagation by tissue culture. Springer Netherlands, Dordrecht, pp 29-64. doi:10.1007/ 978-1-4020-5005-3 2

Grosch R, Faltin F, Lottmann J, Kofoet A, Berg G (2005) Effectiveness of 3 antagonistic bacterial isolates to control Rhizoctonia solani Kühn on lettuce and potato. Can J Microbiol 51:345-353. doi:10.1139/ W05-002

Iordansky AB (1965) Primeneniye tsitazy iz ulitok dlya mikroradioavtografii (use of snail cytase for microradioautography). Tsitologiya 7:120-122 (in Russian)

Levanony H, Bashan Y (1989) Enhancement of cell division in wheat root tips and growth of root elongation zone induced by Azospirillum brasilense. Cd Can J Bot 67:2213-2216. doi:10. 1139/b89-281

López-Lima D, Sánchez-Nava P, Carrión G, Núñez-Sánchez AE (2013) $89 \%$ reduction of a potato cyst nematode population using biological control and rotation. Agron Sustain Dev 33:425-431. doi:10. 1007/s13593-012-0116-7

Maksimov IV, Abizgil'dina RR, Pusenkova LI (2011) Plant growth promoting rhizobacteria as alternative to chemical crop protectors from pathogens (review). Appl Biochem Microbiol 47:333-345. doi:10. 1134/S0003683811040090

Matora LY, Shvartsburd BI, Shchegolev SY (1998) Immunochemical analysis of $\mathrm{O}$-specific polysaccharides from the soil nitrogenfixing bacterium Azospirillum brasilense. Microbiology (Moscow) 67:677-681

Murashige T, Skoog G (1962) A revised medium for rapid growth and bio assays with tobacco tissue cultures. Physiol Plant 15:473-497. doi: 10.1111/j.1399-3054.1962.tb08052.x

Ouchterlony O, Nilsson L-A (1978) Immunodiffusion and immunoelectrophoresis. In: Weir DM (ed) Handbook of experimental immunology, vol 1. Blackwell Scientific, Oxford, pp 19.1-19.44

Paul D, Lade H (2014) Plant-growth-promoting rhizobacteria to improve crop growth in saline soils: a review. Agron Sustain Dev 34:737752. doi:10.1007/s13593-014-0233-6

Pii Y, Mimmo T, Tomasi N, Terzano R, Cesco S, Crecchio C (2015) Microbial interactions in the rhizosphere: beneficial influences of plant growth-promoting rhizobacteria on nutrient acquisition process. A review Biol Fertil Soils. doi:10.1007/s00374-015-0996-1

Rosyidah A, Wardiyati T, Abadi AL, Maghfoer MD (2013) Enhancement in effectiveness of antagonistic microbes by means of microbial combination to control Ralstonia solanacearum on potato planted in middle latitude. AGRIVITA J Agric Sci 35:174-184

Saleh M, Saleh AG (2006) Increased heavy metal tolerance of cowpea plants by dual inoculation of an arbuscular mycorrhizal fungi and nitrogen-fixer Rhizobium bacterium. Afr J Biotechnol V 5:133-142

Tortora ML, Diaz-Ricci JC, Petraza PO (2012) Protection of strawberry plants (Fragaria ananassa Duch.) against anthracnose disease induced by Azospirillum brasilense. Plant Soil 356:279-290. doi:10. 1007/s11104-011-0916-6

Vacheron J, Debrosses G, Bouffaud M-L, Touraine B, Moënne-Loccoz Y, Muller D, Legendre L, Wisniewski-Dye F, Prigent-Combaret C (2013) Plant growth-promoting rhizobacteria and root system functioning. Front Plant Sci 4:356-375. doi:10.3389/fpls. 2013.00356

Venieraki A, Dimou M, Pergalis P, Kefalogianni I, Chatzipavlidis I, Katinakis P (2011) The genetic diversity of culturable nitrogenfixing bacteria in the rhizosphere of wheat. Microb Ecol 61:277285. doi:10.1007/s00248-010-9747-x

Vettori L, Russo A, Felici C, Morini S, Toffanin A (2010) Improving microclonal propagation: effect of Azospirillum brasilense Sp245 on acclimatization of rootstocks of fruit tree. J Plant Interact 5: 249-259. doi:10.1080/17429145.2010.511280

Volkogon VV, Dimova SB, Mamchur AE (2006) Osobennosti vzaimootnoshenii bakterii roda Azospirillum s rasteniyami kartofelya, kul'tiviruemymi in vitro (interaction peculiarities of Azospirillum genus bacteria with cultivated in vitro potato plants). Sel'skokhozyaistvennaya mikrobiologiya 3:19-25 (in Russian)

Zaharchenko NS, Pigoleva SV, Kochetkov VV, Chepurnova MA, Dyachenko OV, Lebedev AA, Zaharchenko AV, Puntus IV, Borodin AV, Buryanov YI (2012) Effect of Pseudomonas and associative methylobacteria on growth and resistance of plants to pathogens and xenobiotics. Russ J Plant Physiol 59:89-98. doi:10.1134/ S1021443711060197

Zamiodis C, Pieterse CMJ (2012) Modulation of host immunity by beneficial microbes. MPMI 25:139-150. doi:10.1094/MPMI-06-110179

Zvyagintsev D (1991) Methods in soil microbiology and biochemistry. Moscow State University, Moscow (in Russian) 